\title{
PENERAPAN E-SCM PADA INDUSTRI OTOMOTIF
}

\author{
Angelita Nauli Panggabean - 2301950881 - LB21
}

E-Business Strategy and Implementation

\begin{abstract}
Abstrak
Perkembangan teknologi telah membentuk pasar berbasis internet di seluruh dunia. Pasar berbasis internet ini telah mendukung banyak industri, salah satunya adalah industri otomotif. Industri otomotif menjadi salah satu kompenen penting dalam pertumbuhan ekonomi negara. Karya tulis ini berfokus pada manajemen rantai pasokan elektronik atau e-SCM di industri otomotif dan dampaknya dari penerapan e-SCM bagi organisasi. Metode yang digunakan oleh penulis adalah metode tinjuan pustaka dimana penulis mencari dan mempelajari jurnal-jurnal, baik nasional maupun internasional di internet. Hasil dari beberapa jurnal yang ditemukan bahwa kemudahan dalam penggunaan dan kegunaan yang dirasakan mempengaruhi adopsi sistem e-SCM dalam organisasi. Disimpulkan bahwa, kegunaan yang dirasakan dan kemudahan dari penerapan teknologi e-SCM dapat meningkatkan kinerja dalam industri otomotif.
\end{abstract}

Kata Kunci: $e-S C M$, Industri Otomotif

\section{Pendahuluan}

Semakin berkembangnya teknologi informasi, mengakibatkan persaingan yang tidak terhindari di bidang binis, sehingga organisasi perlu mengetahui dan menjalankan langkah-langkah dan strategi bisnis yang baik demi tetap bertahan dalam persaingan (Saroso et al., 2019). Pasar berbasis internet atau internet-based electronic marketplaces telah muncul akibat teknologi informasi yang terus berkembang di seluruh dunia. Pasar ini mendukung berbagai industri untuk membantu berbagai pertukaran barang atau jasa (Taghipour et al., 2021). Teknologi sudah menjadi kebutuhan banyak organisasi dan dianggap memiliki kepentingan strategis yang signifikan bagi sebagian besar organisasi (le Tan \& Trang, 2017). Penerapan teknologi ini diharapkan dapat mempermudah, mempercepat proses bisnis, menghembar biaya, waktu, serta tenaga (Saroso et al., 2019). Teknologi juga menjadi faktor penting untuk menciptakan hubungan era tantara pembeli dan hubungan pemasok yang akan meningkatkan proses kolaborasi (le Tan \& Trang, 2017). Berfokus secara khusus pada sistem manajemen rantai pasokan sehubung dengan fungsi pengadaan, industri otomotif memungkinkan akan beralih ke strategi yang lebih dinamis dan inovatif. Organisasi dituntut tidak hanya menghasilkan hasil produksi yang baik, tetapi juga perlu cara penerapan hasil produksi tersebut sampai ke konsumen dengan baik, cepat, dan puas (Faisal \& Andah, 2019). Tentunya hal ini tidak terlepas dari proses operasional perusahaan, mulai dari supplier hingga ke konsumen akhir. Oleh karena itu, Supply Chain Management (SCM) adalah proses penting dimana terjadinya arus pertukaran bahan baku, informasi, dan keuangan antar pihak di sepanjang rantai pasokan (Faisal \& Andah, 2019). Arus pertukaran dalam rantai pasokan ini kemudian 
dikembangkan menjadi electronic Supply Chain Management (e-SCM) akibat dari munculnya pasar berbasis internet yang terus berkembang. E-SCM atau manajemen rantai pasokan ini adalah proses yang melibatkan perusahaan dan mitra yang terintegrasi dengan teknologi yang memungkinkan berbagai proses, tujuan, dan informasi yang relevan untuk seluruh rantai (le Tan \& Trang, 2017). Penggunaan teknologi pada sistem manajemen rantai pasokan atau e-SCM ini didasarkan pada dua prinsip utama, yakni manfaat yang dirasakan dan kemudahan penggunaan yang dirasakan. Namun, penerimaan dan penerapan teknologi pada organisasi tidaklah mudah. Oleh karena itu, karya tulis ini untuk melihat faktor-faktor penting dalam kaitannya penerapan dan penggunaan teknologi, e-supply chain management (e-SCM), dalam rantai pasokan industri otomotif.

\section{Tinjauan Pustaka}

\section{Industri Otomotif}

Industri otomotif merupakan salah satu industri yang berpengaruh di dunia karena melibat berbagai perusahaan yang mengambil bagian dalam desain, pengembangan, menufaktur, penjualan, dan pemasaran mobil maupun suku cadangnya (Masoumi et al., 2019). Dalam pembuatan sebuah mobil, salah satu area dengan biaya terbesar adalah komponen-komponen yang dibeli langsung dari pasokan mereka (Joyce et al., 2019). (Joyce et al., 2019) juga menyebutkan bahwa beberapa pembuat mobil, seperti Ford, GM, DaimlerChrysler, Renault, dan Nissan, saling bekerjasama untuk menggabungkan upaya mereka dalam membentuk pasar elektronik untuk rantai pasokan otomotif yang bernama Convisint pada tahun 2000. Lalu, hingga tahun awal tahun 2016, Covisint masih menjadi software e-SCM pilihan untuk transaksi pengadaan perusahaan otomotif seperti General Motors, Ford Motor Company, Daimler AG (induk Mercedes-Benz), Jaguar, Land Rover, Peugeot-Citroen, dan Mitsubishi. Sampai saat ini, banyak organisasi dalam industri otomotif menggunakan teknologi, seperti e-SCM untuk merampingkan proses sebelumnya.

\section{E-Supply Chain Management (e-SCM)}

Manajemen rantai pasokan (SCM) mengacu pada semua aktivitas yang terkait dengan aliran sumber daya, informasi, barang, dan uang sepanjang rantai pasokan (Erceg \& Sekuloska, 2019). SCM juga didefinisikan sebagai sistem terintegrasi yang terdiri dari subsistem yang saling terakit. Berdasarkan (Widyanesti \& Masyithah, 2018), penerapan manajemen rantai pasokan dapat diartikan sebagai pendekatan yang dilakukan untuk mengintegrasikan berbagai pelaku dalam rantai pasokan, mulai dari pemasok, perusahaan manufaktur atau jasa, distributor, grosir, dan pengecer yang mengantarkan produk, sampai ke konsumen akhir. Perkembangan teknologi informasi telah memberikan tantangan baru bagi SCM, sehingga muncul e-SCM sebagai model organisasi e-binis yang didasari pengunaan elektronik untuk menajalan bisnis, baik secara internal maupun eksternal (Erceg \& Sekuloska, 2019). Dengan kata lain, e-SCM merupakan hasil 
gabungan antara SCM dan teknologi informasi. Menurut (le Tan \& Trang, 2017), e-SCM merupakan sebuah konsep yang dapat digambarkan sebagai jaringan mitra independen yang tidak hanya sebagai distributor produk atau jasa tertentu dalam rantai pasokan, tetapi juga merangsang permintaan dan memimpin sinkronisasi sumber daya di seluruh rantai pasokan. Tujuannya adalah untuk memberikan tingkat efisiensi operasional. Penggerak utama e-SCM adalah koordinasi dan integrasi di antara semua pelaku bisnis dalam rantai pasokan, terutama melalui sistem informasi dan perangkat lunak manajemen yang memadai (Erceg \& Sekuloska, 2019). Efisiensi dan efektivitas e-SCM ini ditentukan oleh keberadaan jaringan informasi dan perangkat lunak yang baik dan interaktif.

\section{Metode}

Metode yang digunakan penulis adalah dengan metode tinjuan pusaaka. Tinjaun pustaka adalah tinjuan tertulis dari sumber-sumber lain tentang topik yang dipilih. Sumber yang tercakup dalam tinjuan dapat mencakup jurnal-jurnal ilmiah. Jurnal-junal tersebut terdiri dari juanl mengenai $e$ $S C M$ dan industri otomotif yang didapatkan dari berbagai sumber di internet.

\section{Kesimpulan}

Pesatnya perkembangan teknologi informasi, telah mengakibatkan persaingan yang ketat dalam berbagai industri dan membentuk pasar berbasis internet. Maka dari itu, organisasi perlu dilakukan dengan menerapkan teknologi dalam setiap proses bisnisnya. Karya tulis ini untuk melihat faktorfaktor potensial dalam kaitannya penerapan dan penggunaan e-supply chain management (e-SCM) dalam rantai pasokan organisasi industri otomotif. Berdasarkan penelitian (Joyce et al., 2019) pada industri otomotif khusunya di Amerika, bahwa kemudahan penggunaan e-SCM dan kengunaan yang dirasakan merupakan dua faktor penting yang berkontribusi pada tingkat penggunaan sistem tersebut. Temuan ini juga sejalan dengan (Bröhl et al., 2016), bahwa kegunaan dan kemudahan dalam penggunaan merupakan komponen kunci dalam penerimaan sebuah teknologi. Dapat disimpulkan bahwa kegunaan yang dirasakan dan kemudahan dari penerapan teknologi e-SCM dalam organisasi ini berkorelasi dengan peningkatan kinerja dalam industri otomotif (Joyce et al., 2019). Maka dari itu, penerapan e-SCM pada industri otomotif memberikan kontribusi positif pada organisasi.

\section{Reference:}

Bröhl, C., Nelles, J., Brandl, C., Mertens, A., \& Schlick, C. M. (2016). TAM Reloaded: A Technology Acceptance Model for Human-robot Cooperation in Production Systems. Communications in Computer and Information Science, 617, 97-103. https://doi.org/10.1007/978-3-319-40548-3_16 
Erceg, A., \& Sekuloska, J. D. (2019). E-logistics and e-SCM: How to Increase Competitiveness. Logforum, 15(1), 155-169. https://doi.org/10.17270/J.LOG.2019.323

Faisal, A., \& Andah, B. D. (2019). Sistem Informasi Berbasis Web Dengan Model Supply Chain Management (SCM) Guna Mengatasi Target Produksi yang Tidak Tercapai pada PT. Jayakurniawan Makmur Sentosa. Jurnal Idealis, 2(2).

Joyce, J., McAllen, D., \& Haddud, A. (2019). A Study of Factors in the U.S. Automotive Industry that Influence Use and Procurement Outcomes for Electronic Supply Chain Management (eSCM). 2019 Proceedings of PICMET '19: Technology Management in the World of Intelligent Systems.

le Tan, T., \& Trang, D. T. D. (2017). Issues of Implementing Electronic Supply Chain Management (E-SCM) In Enterprise. European Business \& Management, 3(5), 86. https://doi.org/10.11648/j.ebm.20170305.13

Masoumi, S. M., Kazemi, N., \& Abdul-Rashid, S. H. (2019). Sustainable Supply Chain Management in The Automotive Industry: A Process-Oriented Review. In Sustainability (Switzerland) (Vol. 11, Issue 14). MDPI. https://doi.org/10.3390/su11143945

Saroso, H., Hida Syahchari, D., Sudrajat, D., \& Grace Herlina, M. (2019). E-Service Quality and Corporate Image on Customer Perception. In International Journal of Innovation, Creativity and Change. www.ijicc.net (Vol. 10, Issue 8). www.ijicc.net

Taghipour, A., Murat, S., \& Huang, P. (2021). E-Supply Chain Management: A Review. International Journal of E-Education e-Business e-Management and e-Learning.

Widyanesti, S., \& Masyithah, S. (2018). Pengaruh Supply Chain Management Practices dan Marketing Capability terhadap Firm Performance melalui Competitive Advantage. Jurnal Ilmiah Manajemen, 8(2), 208-227. https://doi.org/10.22441/mix.2018.v8i2.002 